\section{The American Association for Thoracic Surgery}

\section{Announcement of 2004 Annual Meeting}

$\mathrm{T}$ The Eighty-fourth Annual Meeting of The American Association for Thoracic Surgery will be held April 25-28, 2004, in Toronto, Canada, at the Metro Toronto Convention Centre. The meeting of the Association is open to all physicians. House Officers and Fellows will be admitted without payment of a registration fee upon presentation of a letter from their Chief of Service either during pre-registration or at the time of registration. Nonmember physicians will be required to pay a $\$ 250$ preregistration fee up to March 20, 2004. After that date a registration fee of $\$ 300$ will be required. Members, nonmember physicians, and invited speakers will have the privilege of discussing papers.

\section{Requests for Preregistration Forms and Hotel Reservations}

Information on the 2004 Annual Meeting, including registration, hotel accommodations, and the social program, will be available in January 2004. Requests should be forwarded directly to:

American Association for Thoracic Surgery

900 Cummings Center

Suite 221-U

Beverly, MA 01915

978-927-8330; fax: 978-524-8890

e-mail: aats@prri.com

Registration and hotel information will be available on our Web site at www.aats.org.

\section{Call for Abstracts}

Authors submitting abstracts for the 2004 Annual Meeting must use electronic submission. Abstracts submitted electronically for consideration for presentation at the 2004 meeting must have been received on or before October 10, 2003. Abstracts received after the deadline will not be considered by the Program Committee. The work must not have been presented or reported elsewhere.

\section{Electronic Submission}

Deadline for submission is October 10, 2003. Please submit your abstract via the World Wide Web. All abstract submissions must be in the structured format as required by The Journal of Thoracic and Cardiovascular Surgery. The structured abstract is to contain the following major headings: Objective(s), Methods, Results, and Conclusions, and it should clearly reflect the content of the com- pleted paper. No reference should be made on the abstract to the names or institutions of the authors.

Receipt of each abstract will be acknowledged by e-mail, fax, or mail. Notification of the decision of the Program Committee will be distributed by January 9, 2004.

Essayists selected for the program are reminded that papers presented at the meeting are to be submitted for consideration for publication to The Journal of Thoracic and Cardiovascular Surgery and must be handed to the Chair immediately prior to their presentation.

\section{Walton Lillehei Resident Forum}

The C. Walton Lillehei Resident Forum will be held on Tuesday morning, April 27, 2004. Made possible through an educational grant from St Jude Medical, the Forum will consist of the presentation of original work by residents in thoracic surgical training programs around the world. Abstracts submitted for the award should follow the guidelines of abstract submission for electronic submission noted above. The abstracts submitted for consideration for this Forum will be evaluated by the Program Committee and eight will be selected for presentation during the forum. Each of the selected authors will receive round-trip travel and accommodations for the duration of the AATS annual meeting. Additionally, one presentation will be selected by the Program Committee to receive the AATS C. Walton Lillehei Residents' Award, a $\$ 5000$ prize. Thoracic Surgery Program Directors are urged to have their residents participate in this Forum.

Abstract Deadline-Abstracts received after the deadline will not be considered

Electronic Submission Only: October 10, 2003

\section{Applications for Membership}

Applications for membership in the Association must be received by the Membership Committee Chairman no later than October 3, 2003. Applications received after that date will be deferred automatically for consideration until the 2005 meeting.

Applicants must be sponsored by three Active or Senior Members of the Association who are not members of the Membership Committee. Requests for membership applications may be sent to:

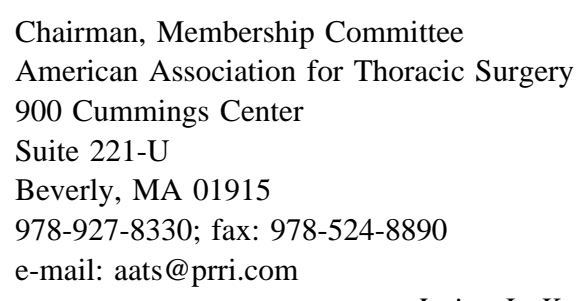

Irving L. Kron, MD, Secretary 


\section{The Western Thoracic Surgical Association}

\section{Announcement of 2004 Annual Meeting}

$\mathrm{T}$ The Thirtieth Annual Meeting of The Western Thoracic Surgical Association will be held June 23-26, 2004, at The Outrigger Wailea Resort in Maui, Hawaii. The scientific sessions are open to all duly qualified physicians. Participation in other Association activities for members, invited guests, and program participants will require payment of a social registration fee.

\section{Requests for Meeting Information}

Meeting preregistration and hotel registration forms are available from:

The Western Thoracic Surgical Association

900 Cummings Center

Suite 221-U

Beverly, MA 01915

978-927-8330; fax: 978-524-8890

wtsa@prri.com

\section{Material for the Program}

Scientific papers will be considered from members and nonmembers. Member sponsorship is not necessary.

For the 2004 Annual Meeting, abstract submission will open on November 10, 2003. All abstracts must be submitted electronically via the WTSA Web site. Information and a link to the submission site will be posted on the Web site closer to November 10. A Call for Abstracts will also be mailed out around that time. Abstracts of proposed papers must be submitted on or before January 9, 2004.

Successful essayists must send the complete manuscript directly to The Journal of Thoracic and Cardiovascular Surgery and must not exceed 3000 words without illustrations. Electronic submissions are to be sent to: http://jtcvs.editorialmanager.com where complete instructions are also available. The essay length must be reduced appropriately when figures or tables are included.

\section{Samson Resident Prize Essay}

The Association offers a prize for the best manuscript on a topic of interest to thoracic surgeons in honor of Paul C. Samson, MD. Candidates for the prize must be in a training program in the United States or Canada. The one essayist whose abstract, manuscript, and presentation are judged most outstanding will receive a $\$ 2000$ cash award following the presentation of all papers in Hawaii. The conditions for abstract submission, presentation, and publication as described above will apply. The authors of the abstracts chosen for the program will make up the finalists and will be notified by mid-February 2004 that they must submit six completed manuscripts for review by the Prize Essay Committee. The Prize Essay committee will make its selection following the presentation of all papers.

\section{Application for Membership}

Applications for membership in the Association must have been received by the Membership Committee Chairman no later than
March 1, 2004, to be considered at the following annual meeting. Applicants must be sponsored by three members of the Association who are not members of the Membership Committee. Application forms will be issued only to sponsoring members.

\author{
Address correspondence to: \\ Chairman, Membership Committee \\ The Western Thoracic Surgical Association \\ 900 Cummings Center \\ Suite 221-U \\ Beverly, MA 01915 \\ 978-927-8330; fax: 978-524-8890 \\ wtsa@prri.com
}

\section{The American Board of Thoracic Surgery}

\section{Notices}

7 he part I (written) examination will be held at the Sofitel Chicago O'Hare Hotel, Rosemont, Illinois, on November 21, 2004. The closing date for registration is August 1, 2004. Those wishing to be considered for examination must request an application since it is not automatically sent.

To be admissible for the Part II (oral) examination, a candidate must have successfully completed the Part I (written) examination.

A candidate applying for admission to the certifying examination must fulfill all the requirements of the Board in force at the time the application is received. Please address all communications to the American Board of Thoracic Surgery, One Rotary Center, Suite 803, Evanston, IL 60201 (telephone: 847-475-1520).

\section{Requirements for Recertification/Maintenance of Certification in 2004}

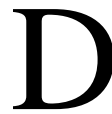
iplomates of the American Board of Thoracic Surgery who plan to participate in the Recertification/Maintenance of Certification process in 2004 must hold an active medical license and must hold clinical privileges in thoracic surgery. In addition, a valid certificate is an absolute requirement for entrance into the recertification/maintenance of certification process. If your certificate has expired, the only pathway for renewal of a certificate is to take and pass the Part I (written) and the Part II (oral) certifying examinations.

The American Board of Thoracic Surgery will no longer publish the names of individuals who have not recertified in the American Board of Medical Specialties directories. The Diplomate's name will be published upon successful completion of the recertification/maintenance of certification process.

The CME requirements include 70 Category I credits in either cardiothoracic surgery or general surgery earned during the 2 years prior to application. SESATS and SESAPS are the 
only self-instructional materials allowed for credit. Category II credits are not allowed. The Physicians Recognition Award for recertifying in general surgery is not allowed in fulfillment of the CME requirements. Interested individuals should refer to the 2004 Booklet of Information for a complete description of acceptable CME credits.

Diplomates should maintain a documented list of their major cases performed during the year prior to application for recertification. This practice review should consist of 1 year's consecutive major operative experiences. If more than 100 cases occur in 1 year, only 100 should be listed.

Candidates for recertification/maintenance of certification will be required to complete all sections of the SESATS self-assessment examination. It is not necessary for candidates to purchase SESATS individually because it will be sent to candidates after their application has been approved.

Diplomates may recertify the year their certificate expires, or if they wish to do so, they may recertify up to 2 years before it expires. However, the new certificate will be dated 10 years from the date of expiration of their original certificate or most recent recertification certificate. In other words, recertifying early does not alter the 10-year validation.

Recertification/maintenance of certification is also open to Diplomates with an unlimited certificate and will in no way affect the validity of their original certificate.

The deadline for submission of applications for the recertification/maintenance of certification process is May 10 each year. A brochure outlining the rules and requirements for recertification/maintenance of certification in thoracic surgery is available upon request from the American Board of Thoracic Surgery, One Rotary Center, Suite 803, Evanston, IL 60201; telephone number: 847-475-1520; fax: 847-475-6240; e-mail: abts_evanston@msn.com. The booklet is also published on the Web site: www.abts.org. 